\title{
THE ROLE OF THE SCOTS IN THE ECONOMY AND SOCIETY OF THE WEST INDIES*
}

\author{
Richard B. Sheridan \\ Department of Economics \\ University of Kansas \\ Lawrence, Kansas 66044
}

Slavery in the New World plantation societies was shaped by physical and institutional environments that varied widely in time and place. The plantation was a multifaceted institution that produced agricultural staples for export markets and came to dominate the larger society under the control of the planter class. Developing in regions of open resources, the plantation required combined and constant labor that was not forthcoming apart from slavery and which yielded a rate of return on both human and physical capital that was high by comparison with that of free labor. The rate of return was, in part, a function of the investment in human capital, both black and white.

The typical sugar plantation was a big business establishment in comparison with contemporary units of industrial and agricultural organization in Europe. It was both farm and factory; it combined the growing of canes with the manufacture of raw sugar and the distilling of molasses into rum. The Reverend Hope Masterton Waddell, a Scottish missionary in Jamaica near the end of slavery, wrote that a sugar estate in good order was a fine sight. The canes presented an appearance of utmost luxuriance and the pastures with their beautiful trees seemed like English parks. The sugar works comprised an extensive range of buildings:

There were the overseer's house and stores, with'the barracks for book-keepers, carpenter, and mason; the mill-house, boiling-house, cooling-house, and still house; the carpenters', coopers', and blacksmiths' shops, and extensive trashhouscs. A little way off stood the hospital or "hot-house;" and on a rising ground overlooking all, the Great House or proprietor's mansion, flanked by the "negro houses" or slave village; these last being buried in cocoa-nut, orange, mango, and avacado-pear trees.'

Waddell said, however, that appearances were misleading, for the typical sugar plantation was neither the abode of contented workers nor a profitable unit of production. Cheerful and willing labor was not to be found. The proprietors or island nobility were for the most part absent. Plantation attorneys, some with many estates under their care, formed the squirearchy of the island. Waddell wrote that every plantation had its own overseer, "who has 'book-keepers,' carpenter, and mason under him. From the attorney down all were unmarried, yet all had families. A married lady was rarely seen. Some planters had not seen one since they left home."1

The Europeans who were attached to sugar plantations-largely, white maleswere organized into a hierarchical structure. In the absence of the proprietor, the attorney had the oversight of the plantation. A mong other things, he ordered

* Research for this paper was supported in part by the National Institutes of Health Grant No. LM-01539 from the National Library of Medicine. 
the plantation supplies, purchased slaves, and superintended the shipment of sugar and rum. He carried out the instructions of his employer, hired and fired the overseers, inspected the plantation records, and reported on the general conduct and performance of the plantation. Besides his handsomę commission, the attorney enjoyed various perquisites which made his position eagerly sought after. ${ }^{2}$.

Underneath the proprietor or attorney was the overseer or manager. On a day-to-day basis he superintended the planting and manufacturing concerns of the plantation. He directed the slaves in their respective tasks and saw that they were supplied with food, clothing, shelter, and medical services. White bookkeepers were in the middle rank, being under the overseers or managers and immediately above the black drivers. White artisans who were assisted and not infrequently supplanted by their mulatto and black apprentices consisted of carpenters, millwrights, wheelwrights, masons, coopers, ropemakers, and distillers. Medical services were provided by white doctors, who were assisted by black doctors, doctresses, nurses, and midwives. ${ }^{3}$

The expansion of the sugar industry-and to a lesser extent the production of coffee, cotton, and other minor staples-raised the problem of recruiting competent managerial and professional personnel. By the third quarter of the eighteenth century the West Indies no longer served as dumping grounds for English prisoners of war, dissenters, convicts, prostitutes, orphans, and vagrants. Moreover, it became increasingly difficult to attract voluntary indentured servants because of the high cost of living, the competition of slave artisans, and the more attractive prospects in North America. ${ }^{4}$

\section{II}

Scottish vessels were reported to have carried goods to Barbados in the first year after the Act of Union of 1707. In 1735, Glasgow dispatched fifteen ships to Virginia, four to Jamaica, two to St. Kitts, and one each to Barbados and Antigua. 5,6 Exports consisted of a variety of goods, with Scottish-made linen being the export of greatest value. After the collapse of the Virginia market at the outbreak of the American Revolution, Jamaica alone took off 40 percent of all Scottish linen exports to be made up into clothing for the planters and their slaves. Other exports consisted of haberdashery, goods of leather, iron, copper, tin, hats, ropes, delft and stoneware, herrings, and coaches. From the Caribbean Scots vessels returned with sugar, rum, coffee, raw cotton, indigo, nutmeg, cochineal, tobacco, hides, logwood, fustic and other dyewoods. During the American War Scottish trade made a significant shift from the North American mainland to the British West Indies. Raw cotton from the West Indies played an important role in the early development of the Scottish cotton industry, while the restrictions imposed by the British government on trade between the United States and the British West Indies gave a fillip to the export of Scots herrings. ${ }^{7-10}$

Trade with the West Indies was a stepping stone to the acquisition of plantations. This was especially the case after the shipping and trade of Glasgow and Edinburgh were established on a regular basis, for it was customary for merchants to then employ their countrymen as resident agents or factors, who were in a favorable situation to commute mercantile capital into planter capital. The ownership or control of plantations enabled Scotsmen to employ their countrymen in a variety of craft, managerial, and professional capacities. Other Scotsmen came to the West Indies to fill posts in government and military units. As with 
the merchants and factors, many officials and officers acquired plantations, some by the expedient of marriage to sugar heiresses. $\dagger$

No sooner was one Scotsman established in the islands than he began to send for his relatives, friends, and former neighbors. Recruiting was accomplished by means of correspondence, verbal instructions to masters of ships, and newspaper advertisements. For example, the Glasgow Courier carried the following "situations wanted" advertisement:

Wanted for the Island of Jamaica-

1 Blacksmith; 2 Coppersmiths; 4 Plumbers:

1 Joiner; 2 Book-keepers;

2 Young men bred in the Farming Line to act as Planters; to whom liberal encouragement will be given. ${ }^{12}$

Generally speaking, the Scotsmen who made their way to the colonies were well educated. From the village primary schools through the universities, the Scottish educational system was of superior quality and more nearly universal than that of England and most countries in Europe. Smollett's Roderick Random said that it was not to be wondered at if he had a tolerable education, for learning was so cheap in Scotland that "every peasant was a scholar."13,14 Scotland's five universities gained fame for their scientific, technical, and professional work, especially in the fields of chemistry, medicine, engineering, and political economy. Students came from near and far. The matriculation albums of the University of Glasgow from 1728 to 1800 show a total of 84 students who came from the West Indies, distributed as follows: 43 from Jamaica, 17 Antigua, 10 St. Kitts, 6 Barbados, 4 Nevis, and 2 each Montserrat and St. Vincent. ${ }^{15}$ Graduates in medicine at the University of Edinburgh who came from the West Indies in the period from 1744 to 1834 totaled 230 , of whom 86 came from Jamaica, 52 Barbados, 20 Antigua, $19 \mathrm{St}$. Kitts, 13 West Indies in general, $12 \mathrm{St}$. Croix, 4 each Nevis, St. Vincent, Dominica and Trinidad, 3 each Montserrat and Berbice, 2 each Grenada and Demarara, and 1 each St. Martin and St. Eustatius. ${ }^{16}$ Besides the graduates there were 127 Jamaicans who matriculated at the University of Edinburgh Medical School from 1759 to 1834.17

There were some potent political causes for Scots emigration to the Caribbean. By the terms of the Union of 1707 , Scotland sent to the Parliament at Westminster forty-five members of the House of Commons and sixteen representative peers to sit in the House of Lords. The Scottish M.P.s generally voted in a bloc and traded their votes in return for advantages for Scotland. Among other advantages they sought civil and military posts for their countrymen in the colonies. Numerous governors, customs collectors, military and naval of ficers came from Scotland to the West Indies. For example, Archibald Hamilton, brother to the Duke of Hamilton, was made governor of Jamaica in 1711. A great number of Scots and Irish gentlemen who expected to make fortunes followed the new governor to Jamaica where they reportedly gave disgust to the inhabitants. ${ }^{18}$ Samuel Martin of Antigua wrote to his eldest son and namesake, the Member of Parliament, on December 30,1774, informing him that the offices in that island were generally given to Scotsmen, by the influence of Lord Mansfield. 19

Other Scotsmen were transported to the West Indies after suppression of the Highland rebellions of 1715 and 1745 . Measures were taken to incorporate the rebel Highlanders into the several regiments stationed in the West India colonies. 
After the rebellions many tenant farmers in the Highlands were forced to emigrate because their rents were raised, arable land was converted into sheep runs, and crop failures reduced them to dire necessity. While the greater number of Highlanders went to the North American colonies and especially to North Carolina, ${ }^{20}$ not a few emigrated to the West Indies. Janet Schaw told of "a company of hapless "exiles" from the Orkney Islands who were privately put on board the ship Jamaica Packet, which she and her brother took from Edinburgh to Antigua in October 1774. Most of the Highland emigrants on this voyage settled in Antigua. "Besides the company of Emigrants," she wrote, "there was a Smith with his wife, two taylors and a handsome young Cooper. These were voluntarily going to the West Indies, to mend or make their fortune, so had no claim to that pity the others had a right to."'21

During Janet Schaw's lifetime all but a few of the Scotsmen who went to the West Indies emigrated voluntarily and with a view to mend or make their fortunes. Richard Pares has observed that Scotland was a country poor in natural resources but possessed of an educational system several sizes too large for it. ${ }^{22}$ Not only did middle-class Scots leave home because all the professions were overcrowded, but yeomen farmers and craftsmen also sought opportunities in the colonies. In 1786, Robert Burns obtained through friends in Ayrshire the offer of a position at thirty pounds a year as bookkeeper on a Jamaican plantation, his employer to pay his fare and deduct the sum from his first year's salary. He had actually packed his trunk for the voyage to Jamaica when he was persuaded to remain in Scotland upon learning of the success of his first volume of poems. ${ }^{23}$

\section{III}

Probably the greater number of Scotsmen began their careers in the West Indies as bookkeepers or overseers. These subalterns at the lowest rung of the plantation ladder led a life of such hardship and hazard that they often regretted having left their native land. The Reverend William Jones, an Anglican clergyman in Jamaica, told of a young Scotsman who came to that island as a bookkeeper. He was sent to the field with the slaves and expected to "curse, swear \& abuse" them. Jones regretted to learn that the shock that the young man first professed to feel at the barbarous treatment of the blacks seemed to be gradually wearing off. Because he refused to launch into the same excesses of drunkenness and debauchery as the rest of the bookkeepers, the young man was branded a "novice" and "greenhorn." Despite his abstinence his health failed and he became a "feeble, palsied, death-like figure of a man." Jones estimated that hardly one out of twenty or thirty of the bookkeepers in Jamaica survived a second or third year at most. 24

James Stephen, the barrister and antislavery leader, was another poor son of a Scotsman who, like Robert Burns, nearly went to Jamaica as a bookkeeper. Stephen later went to St. Kitts as a barrister and learned much about the institution he helped to destroy. In his Memoirs he wrote of the bookkeeper who, among other duties, had to "endure the noontide blaze of a tropical sun while surveying the labours of the field, and the steam of the boiling house by night." His food was for the most part salted meat, which contributed to excessive drinking of rum to quench his thirst. Only a constitution of the strongest kind could sustain the hardships and privations to which these young men were exposed. Stephen wrote that the posts of bookkeeper or overseer were "commonly filled by hardy young men from Scotland and Ireland taken from the ranks of life not much above the lowest, and who are prepared by early habit to sustain well every physical hardship." 25 
The Stephen family was one of a number of Scots families that were prominent in the professional and planting life of the West Indies. In his Memoirs, James Stephen wrote of his uncle William Stephen who was a doctor in St. Kitts. One way he made considerable gains was by "purchasing what are called 'refuse negroes' at the Guinea Yard Sales in the Island he lived in, and curing them and then reselling them in their healthy state at prices greatly advanced." 26 Uncle William's practice prospered and he took his nephew William, brother of James Stephen, as an apprentice and later sent him to Aberdeen and Edinburgh to study medicine. Brother William returned to St. Kitts before completing his degree and succeeded to his uncle's practice and estate. He was convinced that "the only roads to independency and fortune in the West Indies are the learned professions, or that success in the planting line is at least very difficult and rare, and of slow growth to men who do not set out either with capital or credit."27 $\mathrm{He}$ was probably influenced in this belief by his uncle William's having been tempted into the "planting lottery" by the purchase of an estate in Dominica. James Stephen's uncle John had quit the East India Company service and gone to Dominica to manage his brother's plantation. 28

Dominica together with the islands of St. Vincent, Grenada, and Tobago which were acquired by Great Britain by the Treaty of Paris in 1763, was to a considerable extent settled by Scotsmen. Sir William Forbes, the Edinburgh banker, recorded in his Memoirs that "extensive speculations were entered into by some Scotchmen for the purchase and cultivation of lands in the newly acquired West India Islands." 29 Men with Scots surnames purchased about 16,000 out of a total of 72,000 acres in Grenada, ${ }^{30}$ and other large purchases were made in the other Ceded Islands. Sir William Young, the son of a Scots doctor in Antigua, purchased 2,300 acres in Tobago and another 835 in Dominica. ${ }^{31,32} \mathrm{He}$ was licutenant-governor of Dominicain 1768-74, and father of the second baronet by the same name who was governor of Tobago and leader of the West India interest in the House of Commons. ${ }^{33}$ Among other large landholders was General Robert Melville, who played an important part in the capture of the Ceded Islands and became captain general and governor in chief of these islands. He established the famous botanical garden in St. Vincent. ${ }^{34}$ Political influence contributed to the coming of many Scotsmen to the Ceded Islands, for Lord Bute, who was a Scotsman, was prime minister when these islands were acquired, and John Campbell, who publicized these islands in two pamphlets, was a Scot tish lawyer of wide interests and considerable capacity and a friend of Lord Bute. ${ }^{35}$

The colonies of Trinidad and Guyana, which were conquered by Great Britain during the Napoleonic Wars, became new fields for Scots enterprise. Trade, shipping, and finance for the new colonies became major undertakings for the merchants and bankers of Glasgow and Edinburgh. ${ }^{36}$ Numbers of Scotsmen migrated to these colonies. The Scots in Guyana possessed in a marked manner the shrewdness and tact necessary to personal aggrandizement and were more successful in business than were most of the other settlers from England or Ireland. ${ }^{37}$ One of the most successful men who combined planting with trade and finance was John Gladstone, father of the Prime Minister. He was born and raised in Scotland and later became established as a leading merchant and politician at Liverpool. He owned seven sugar plantations in Guyana and was full or part owner of six others in Jamaica. Gladstone received compensation money from the British Government at the time of slave emancipation amounting to $\mathfrak{f} 85,600$ for 2,183 slaves. 38,39 
Jamaica, which was by far the most important tropical colony in the British Empire, attracted great numbers of Scotsmen. In the early part of the eighteenth century Glasgow supplied large numbers of indentured servants who were kidnapped by man traders and sold upon their arrival in Jamaica for terms of four or five years. ${ }^{40}$ However, this forced labor trade came to an end, partly in reponse to the' need for better-educated recruits. In his Account of Jamaica of 1739, the Scotsman Charles Leslie wrote that servants who behaved well were respected and encouraged; "if they are found honest and worthy of their Trust they are handsomely used." Leslie also noted that several of his countrymen had made fine estates in Jamaica from very small beginnings. He singled out a Mr. Barclay who was first a factor and soon got a vast business that ranked him among the richest traders in the island. 41

Particular attention was given to the activities and achievements of Scotsmen and Irishmen by Edward Long, the historian of Jamaica. He thought that the natives of those countries thrived better than the European English because of their sounder constitutions and an ethnic patronage system that provided employment and friendly protection. In a vein of almost unbounded praise, Long wrote that

Jamaica, indeed, is greatly indebted to North Britain, as very near one third of the inhabitants are either natives of that country, or descendants from those who were. Many have come from the same quarter every year, less in quest of fame, than of fortunes; and such is their industry and address, that few of them have been disappointed in their aim. To say the truth, they are so clever and prudent in general, as, by an obliging behaviour, good sense, and zealous services, to gain esteem, and make their way through every obstacle. ${ }^{42}$

One group that came from the same quarter consisted of some one hundred of the name of Campbell, who all claimed alliance with the Argyle family.43

Possessing much land suitable for plantation agriculture and having large numbers of absentee proprietors, Jamaica developed a highly articulated plantation ladder which numerous Scotsmen climbed to the very top. After passing through a regular course of service as bookkeepers, Scots overseers who were sensible and thrifty saved enough of their salaries to buy settlements of their own. Long wrote that "some of them have even become possessors, in time, of very large properties, and made a very respectable figure here." 44 Once established as proprietors, ambitious Scotsmen pushed on to become plantation attorneys, money lenders, shipowners, and wielders of economic and political power, both in the colony and mother country.

Simon Taylor was one of these "sugar tycoons," whose story has been told by the author. He was born in Jamaica, the son of a Kingston merchant who came from Scotland. At one time or another Taylor possessed six sugar estates and three cattle ranches or pens. He was also the island's leading plantation attorney, member of the legislative assembly, chief justice, custos, and licutenantgeneral of militia. A bachelor, he was said to have lived principally with overseers of estates and masters of merchant vessels when he was not engaged in public business or entertaining the island's dignitaries. Lady Maria Nugent, wife of Governor Sir George Nugent of Jamaica, said that Simon Taylor was the richest man in the island and was determined to make his nephew the richest commoner in England. 45

There is no reason to doubt that the economy and society of Jamaica was influenced profoundly by the Scots community. As early as 1777 a Scots 
merchant informed Ezra Stiles, President of Yale College, "that (as in Jamaica) the Scotch had got Two Thirds of Virginia \& Maryld. mortaged or otherwise engaged to them or was owned in Scotland." 46 Lady Nugent was in a party that was shown around Hope estate near Kingston by the overseer, who was described as "a civil, vulgar, Scotch officer, on half-pay." She did not contradict his brother Scotsman who told her that he was a good overseer, "as almost all the agents, attornies, merchants and shop-keepers, are of that country, and really do deserve to thrive in this, they are so industrious." 47 Professor Patterson has called attention to Scottish cultural influences, observing that "the free coloured and many of the creole slaves who consciously sought to assimilate the culture of the whites tended to imbide Scottish customs, especially in the area of recreation." 48

\section{IV}

Scotsmen were sometimes criticized for subordinating sentiments of humanity to the single-minded pursuit of wealth. They were accused of exacting extraordinary labor from and meting out harsh punishment to slaves. James Ramsay, himself a Scotsman, observed from his long experience in St. Kitts "that adventurers from Europe are universally more cruel and morose toward slaves, than Creoles, or native West Indians." 49 Mrs. A. C. Carmichael, a Scots lady and wife of a Scots planter in St. Vincent, said that, generally speaking, the Negroes did not regard England and Scotland in the same light. She believed that this proceeded from two causes: "Scotchmen are proverbially active and economical, abroad as well as at home: and perhaps there are not two qualities which the majority of negroes dislike more thoroughly." One of her own slaves categorized Scotsmen as "all mean, hold-purse fellows ... Dey go mean, me no like dem." 50 Part of the difficulty was that the absentee proprietor judged his attorney and overseer by the quantity of produce extracted from his plantation and shipped to Europe, not knowing and sometimes not caring if the forced labor increased the mortality of his slaves. 51

Perhaps the most penetrating analysis of plantation management was that made by Augustus Hardin Beaumont, a Jamaican plantation overseer who testified before the House of Commons Select Committee on Apprenticeship in 1836. "Persons who are called par excellence planters and planting attornies," he said, "in general have been young men sent from Scotland, and are occasionally the sons of Jamaica proprietors, born in the island." 52 Though they supervised the labor of the slaves, the Scotsmen were said to have kept perfectly aloof from them and knew nothing about their real character and opinion but what they obtained from their black or brown mistresses, "which every planter (or bookkeeper as he is called) keeps and changes, either at caprice, or as he changes the estates on which he is learning to become a planter." When the bookkeeper became the overseer of a plantation, he generally performed his duties through a Negro headman who knew the routine of the business a great deal better than he did. 52

Overseers and proprietors who became great plantation attorneys had from thirty to fifty or sixty, and even in a few cases one hundred plantations under their control, Beaumont testified. The attorney, he said,

. . pays to each an annual visit of a day, when the negroes are to receive their clothing, rides round the canes, says a few words to the head-driver, commends or finds fault with the manager, dines and possibly sleeps on the estate, then proceeds to another plantation for the same purposes. 
Beaumont contended that the attorney did not know and could not know anything of the real feelings and opinions of the laboring population. 52

What is most revealing about Beaumont's testimony is his statement that many plantations in Jamaica were practically managed by black men. This statement applied to at least twenty-eight plantations with which he was familiar. He named one great plantation attorney with some fifty plantations under his care who "usually lived in the town of Falmouth, and left the management to the overseer, who, in fact, managed by means of the headmen. I have known estates managed for weeks together entirely by the blacks, and very well managed." $53 \ddagger$

Although Beaumont's unorthodox views are difficult to verify, his testimony does raise an important issue about the purpose of plantation management. Plantations with passive white managers and active black headmen might be well managed from the standpoint of the welfare of white and black Creoles, but at the sacrifice of the interests of the white power structure. Getting the greatest quantity of sugar out of the greatest quantity of labor meant increasing the ratio of working slaves to total slaves, operating the mills and boiling houses both day and night, and driving the field slaves in quasi-military formations. It was the purpose of the plantation system to maximize production and profits by the employment of forced labor, and to channel the produce to the beneficiaries of that system in the metropolis. Plantation attorneys and resident proprietors served as connecting links between subordinate whites, mulattoes and blacks in the colonies and the merchants, shipowners, commission agents, bankers, manufacturers, and absentee proprietors who were the ultimate beneficiaries of the system in the metropolis. West Indians repatriated wealth and income to Scotland as well as to England. Indeed, there may have been as many Scotsmen as Englishmen who returned from the West Indies to live in opulence on the income of their plantations after about $1750 . \S$

\section{V}

Beaumont's characterization of Scotsmen as alienated from the slaves they directed and interested solely in production and profit is a half-truth. It fails to recognize that many Scotsmen and other Europeans in the West Indies were long-term economic maximizers in the sense that, while not opposed to slavery, they supported measures of amelioration that they considered necessary to improve demographic performance and to have a slave population that at least reproduced itself. A second group of Scotsmen was imbued with scientific, professional, and humanitarian values and concerns, although they did not break with the dominant proslavery ideology of the plantocracy. $A$ third group was repulsed by the crass materialism of the plantocracy and the brutality and inhumanity of slavery and joined in the crusade against the peculiar insitution and the sugar monopoly of the home market upon which it rested.

Before the rise of humanitarian amelioration some Scotsmen were active in the movement toward economic amelioration. "As an economic measure," writes

$\ddagger$ For the activities of slaves as overseers or general managers of plantations in the antebellum South of the United States, see Time on the Cross: The Economics of Amcrican Negro Slavery. 54

§According to William Beckford, large portions of the land of Scotland "have been cleared, cultivated, and peopled, by the weath that has been acquired in the Islands: and this fact may be easily ascertained and proved."ss,ss 
J. Harry Bennett, "amelioration can be defined with substantial accuracy as a system by which money that would otherwise have been spent on hiring and buying Negroes was used to improve the lot of the existing stock of slaves in order to induce them to breed their replacements." This movement commenced in Barbados during the 1760s, when some proprietors turned from a policy of hard driving, high mortality, and frequent replacements to one of encouraging their slaves to breed by humane treatment. 57

As the best-educated section of the white population in the West Indies, the Scots combined business and professional careers with scientific and academic avocations that kept them abreast of European cultural achievements. They kept careful records of meteorological and geological phenomena, collected and preserved specimens of flora and fauna, collected vital statistics, studied the ethnology and folklore of the Amerindians and Afro-Americans, and added African folk remedies to their materia medica. Moreover, they published articles and books and corresponded with some of the great men of their age. For example, A. J. Alexander, a plantation manager in Grenada, wrote to Dr. Joseph Black, Professor of Chemistry at the University of Edinburgh, recalling his student days and describing the diseases contracted by the slaves and the remedies for the same. In his leisure hours Alexander read books and carried out chemical experiments that were recommended to him by Professor Black. 58 Dr. John Lindsay, rector of the parish church at Spanish Town, Jamaica, wrote lengthy letters to Dr. William Robertson, Principal of the University of Edinburgh and famous historian. In one letter he enclosed the vital statistics of his parish. 59

Scottish doctors were probably the best educated and certainly the most numerous group of professionals in the West Indies. They ranged from what one contemporary described as "druggists boys from Glasgow and Aberdeen" to medical graduates from the universities at Edinburgh, Glasgow, and Aberdeen. ${ }^{60}$ That some of the doctors combined medical practice among the whites and blacks with scientific and humanitarian interests may be illustrated by sketching the careers of three Edinburgh graduates who practiced in the West Indies.

Dr. James Grainger (1721?-1766) was an army surgeon and later an unsuccessful practitioner in London, where he turned to literary pursuits and attracted the attention of Samuel Johnson and Oliver Goldsmith. In 1759, he went to St. Kitts, married a sugar heiress, and practiced medicine. In his leisure time he studied botany and wrote two books: one a long poem on the sugar-cane; the other an essay on West Indian diseases. Grainger's medical Essay was principally intended for the use of owners and managers of slaves in the sugar colonies. He pioneered in calling attention to the medicinal value of numerous indigenous plants of the West Indies. ${ }^{61}$

Dr. William Wright, F.R.S. (1735-1819), was a surgeon's mate on several naval vessels and also a hospital surgeon in the West Indies. He settled in Jamaica in the late 1760s where he and his medical partner established a substantial plantation practice. After acquiring a plantation of his own, he devoted many years to scientific and literary pursuits, which included natural history collection and the publication of scientific papers on slave medicine. He saw the second edition of Grainger's Essay through the press in 1802, to which he added an introduction, practical notes, and a "Linnaean Index."62

Dr. James Thomson (?-1822), was a student at Edinburgh when he was strongly advised by Dr. Wright to go to the West Indies and institute inquiries into the disorders to which the Negroes were liable. In 1820, Thomson published a Treatise on the important diseases of the Negroes, which he intended to be of service to planters and their managers. He found merit in certain folk medical remedies and 
respected other aspects of the slaves' culture. He observed that professional duties gave doctors a knowledge of the most minute domestic arrangements of the blacks which were known only to those in habits of the closest intimacy. ${ }^{63}$

Though numerous Scotsmen were repelled by the brutality and inhumanity of slavery, three stand out as leaders of the antislavery movement. James Ramsay (1733-1789) was born in the north of Scotland, was apprenticed to a surgeon and later attended King's College, Aberdeen. He was assistant to a doctor in London for two years, after which he became a surgeon in the navy. Ramsay developed an antipathy to slavery when he was called upon to assist a slave vessel that was infected with the plague. After leaving the navy he took holy orders and settled at St. Kitts as an Anglican clergyman. Along with his pastoral duties, he practiced plantation medicine and began a scheme for the religious instruction of slaves. Ramsay was later to write that it was the working of slaves beyond their ability that shortened their lives and checked their population. ${ }^{(r)}$ His criticisms of the treatment of slaves raised bitter opposition, and he was attacked in pamphlets and newspapers articles and ostracized by the planters. After nearly twenty years in the West Indies, Ramsay, in 1781, accepted the livings of Teston and Nettlestead in Kent. At the encouragement of his friends he revised and published his Essay on slavery, which was the most important event in the early history of the antislavery movement. Because of his long experience with slavery, Ramsay was frequently consulted by Pitt, Wilberforce, Clarkson and other abolitionist leaders. ${ }^{65}$

We have seen that James Stephen $(1758-1832)$ had several relatives in the West Indies who were engaged in the medical profession and planting. Born at Poole in Dorset, the son of a Scotsman who died in poverty, Stephen was helped by his brother William and other relatives to get an education. After being called to the bar in 1782, he sailed for St. Kitts. His first experience with slavery occurred at Barbados, where his vessel touched on its way out. He was so shocked at the brutality shown to some Negroes at their trial for murder that he vowed he would have nothing to do with slavery. For some years he practiced at the bar at St. Kitts with considerable success. He supplied Wilberforce, who later became his brother-in-law, with private information to support the antislavery cause. Returning to England, Stephen practiced as a barrister and later was elected to the House of Commons. He was a prolific writer on legal, political, and humanitarian subjects. Indeed, his two-volume work on slavery in the West Indies is one of the classics of emancipationist literature. 66

Zachary Macaulay (1768-1838) was born in Argyllshire, the younger son of a Presbyterian minister. As a boy he was placed in a counting house in Glasgow and devoted his leisure to study and association with local university students. By the influence of Sir Archibald Campbell, a former governor of Jamaica, Macaulay was sent out at the age of sixteen to be a bookkeeper of a sugar plantation in that island, of which he later became overseer. In an autobiographical sketch he recalled,

My office was laborious, irksome, and degrading in a degree of which I could have no previous conception, and which none can imagine fully who, like me, have not experienced the vexatious, tyrannical, pitiless, and capricious conduct of a Jamaica Overseer. To this, however, I made it a point to reconcile my mind. I saw, I thought, that there was no medium between doing so and starving. ${ }^{67}$

Macaulay remained in Jamaica about five years. He returned in England in 1792 , and the following year sailed to Africa where he became governor of the colony of liberated slaves at Sierra Leone. Thrusting himself into the crusade against 
the slave trade, Macaulay took passage to the West Indies in a slave ship to learn of the horrors of the "middle passage." After his return to England in 1799, he served as secretary of the Sierra Leone Company and later of the African Institute, and was active in the Anti-Slavery Society. His long service in the cause of the blacks was commemorated by Sir James Stephen, son of the barrister and himself an antislavery leader, who wrote that Macaulay "meekly endured the toil, the privation, and the reproach, resigning to others the praise and the reward." 68

\section{VI}

Numerous Scotsmen went to the West Indies to begin their careers as bookkeepers. Those who survived the "seasoning" climbed the plantation ladder as overseers, managers, proprietors, attorneys, and sugar tycoons. Others who went out as artisans, merchants, doctors, lawyers, officeholders, and soldiers frequently succeeded in mending or making their fortunes. Notwithstanding their image as "all mean, hold-purse fellows," Scotsmen varied widely in their attitude toward slavery and their ability to maintain professional and humanitarian standards of behavior in the face of a corrupt and tryannical society. If the greater number sank to the prevailing level of white colonial society, others found ways to mitigate the condition of the slave economy and society. Most remarkable were the doctors, lawyers, clergymen, and overseers who were appalled by the conditions of black servitude they witnessed and drew on their experience to give leadership and direction to the abolition and emancipation movements.

\section{NOTES AND REFERENCES}

1. WADDELL, H.M. REV. 1863. Twenty-Nine Years in the West Indies and Central Africa: A Revicw of Missionary Work and Adventure 1829.1858, 2nd ed. :20-21 Reprinted in 1970 by Frank Cass \& Co., Ltd. London, England.

2. SHERIDAN, R. B. 1971. Simon Taylor, Sugar Tycoon of Jamaica, 1740-1813. Agricultural History XLV (4) :287-288.

3. SHERIDAN. R. B. 1974. Sugar and Slavery: An Economic History of the British West Indics 1623-1775. :257-259, 372-374, 377-381. Johns Hopkins University Press. Baltimore, Md.

4. Ibid. :237, 380-381.

5. MACARTHUR, W. F. 1932. History of Port Glasgow. :69-70. Jackson, Wylie \& Co. Glasgow, Scotland.

6. DONALDSON, G. 1966. The Scots Overseas. :43-44. Robert Hale. London, England.

7. DURIE, A. J. 1973. The markets for Scottish linen, 1730-1775. The Scottish Historical Review LII (153):30-49.

8. CRISPIN. B. 1962. Clyde shipping and the American war. The Scottish Historical Review XLI (132): 124-134.

9. HAMILTON, H. 1963. An Economic History of Scotland in the Eighteenth Century. :261-267, 270-272, 279-281.

10. ANON. 1961. The Rise of Glasgow's West Indian trade, 1793-1818. The Three Banks Review 51 (September) :34-44.

11. SHERIDAN, R. B. 1961. The rise of a colonial gentry: A case study of Antigua, 17301775. The Economic History Review, 2nd ser. XIII, (3) :342-357.

12. Quoted without date of publication in ANON. 1962. An early Glasgow-West Indian miscellany. The Three Banks Review 54 (June) : 35 .

13. SMOLLETT, T. The Adventures of Koderick Random. :251. Signet Classic, The New American Library. New York, N.Y.

14. PARES, R. 1961. A quarter of a millennium of Anglo-Scottish Union. The Historian's Business and Other Essays. R. A. and E. Humphreys, Eds. :90-95. Clarendon Press. Oxford, England.

15. ADDISON. W. I. 1913. The Matriculation Albums of the University of Glasgow from 1728 to 1858. :13-80. James Maclehose and Sons. Glasgow, Scotland. 
16. List of the Graduates in Medicine in the University of Edinburgh, From MDCCV to MDCCCLXVI 1867.:2-102. Neill and Co. Edinburgh, Scotland.

17. MS. Medical Matriculation Albums. University of Edinburgh Library.

18. The Modern Part of an Universal History: From the Earliest Account of Time. 1764. XLI :387-388. London, England.

19. Samuel Martin to Samuel Martin, Jr., M. P. in Westminster, dated Antigua, December 30, 1774. In Martin Papers, vol. III, British Museum Additional MSS. :41,348, f. 204.

20. GRAHAM, I. C. C. 1956. Colonists from Scotland: Emigration to North America, 1707-1783. :23-89. Cornell University Press. Ithaca, N.Y.

21. SCHAW, J. 1923. Journal of a Lady of Quality; Being the Narrative of a Journey from Scotland to the West Indies, North Carolina, and Portugal, in the Years 1774 to 1776. E. W. Andrews and C. M. Andrews, Eds. :33, 55. Yalc University Press. New Haven, Conn.

22. PARES, op. cit. :94-95.

23. FERGUSON, DEL. 1939. Pride and Passion: Robert Bums 1750.1796. :188-193. Oxford University Press. New York, N.Y.

24. CHRISTIE, O.F., Ed. 1929. The Diary of the Rev. William Jones, 1777-1821.:43-46. Brentano's. London, England.

25. STEPHEN, J. 1954. The Memoirs of James Stephen: Written by Himself for the Usc of His Children. M. M. Bevington, Ed. :169-170. The Hogarth Press. London, England.

26. Ibid : 42 .

27. Ibid. : 173 .

28. Ibid. :46.

29. FORBES, W. SIR. 1860. Memoirs of a Banking.House. :39. William and Robert Chambers. London and Edinburgh.

30. PATERSON, D. 1780. A Topographical Description of the Island of Grenada.:6-13. London, England.

31. FOWLER, J. 1774. Of the present Flourishing State of the Respectable Colony of Tobago, in the British West Indies. :32-57. London, England.

32. BYERS, J. 1777. References to the Plan of the Island of Dominica. :6. London. England.

33. OLIVER, V. L. 1894-99. The History of the Island of Antigua, etc. (3 vols.) Vol. III. :280. London, England.

34. Memoirs of the late General Melville. The Scots Magazine, February and March, 1810: $97 \mathrm{ff} ., 169 \mathrm{ff}$.

35. SHERIDAN, Sugar and Slavery, op. cit. :452-459.

36. ANON. An Early Glasgow-West Indian Miscellany. op. cit. :29-38.

37. DALTON, H. G. 1855. The History of British Guiana, ctc. (2 vols.) Vol. 1:306.308. Longmans. London, England.

38. CHECKLAND, S. G. 1971. The Gladstones: A Family Biography 1764-1851. :1-16. 74-77, 119-128, 185-199. Cambridge, University Press. Cambridge, England.

39. WILliAMS, E., 1944. Capitalism and Slavery. :90. University of North Carolina Press. Chapel Hill, N.C.

40. LONG, E., 1774. The History of Jamaica (3 vols.) Vol. II:287. London, England.

41. LESLIE, C. 1739. A New and Exact Account of Jamaica, etc. :320, 357. Edinburgh, Scotland.

42. LONG, op. cit. :286-287.

43. Ibid. :286.

44. Ibid. :287.

45. Lady Nugent's Journal of Her Residence in Jamaica from 1801 to $1805 .: 64-65,68$, $126,181,212$. A new and revised edition by P. Wright. 1966. Institute of Jamaica. Kingston, Jamaica.

46. DEXTER, F.B., Ed. 1901. The Litcrary Diary of Ezra Stiles, D.D. LL.D. President of Yale University ( 3 vols.) Vol. II:227-228.

47. Lady Nugent's Journal, op. cit. :29.

48. PATTERSON, O. 1967. The Sociology of Slavery: An A nalysis of the Origins, Devclopment and Structure of Negro Slave Socicty in Jamaica. :45-46. MacGibbon and Kec. London, England.

49. RAMSAY, J., REV. 1784. An Essay on the Treatment and Conversion of African Slaves in the British Sugar Colonies. :67-68. London, England.

50. CARMICHAEL, A. C., MRS. 1833. Domestic Mlanners and Social Condition of the White, Coloured, and Negro Population of the West Indies (2 vols.). Vol. I: 321-322. London, England. .

51. [COLLINS, D. DR.], 1971 (reprinted). Practical Rules for the Monagement and Micdi. 
cal Treatment of Negro Slaves, in the Sugar. Colonies. By a Professional Planter. :1516. Books for Libraries Press. Freeport, N.Y.

52. Report of the Select Committee on Apprenticeship, 19th July, 1836. British Sessional Papers, House of Commons, 1836, Vol. XV: 388; testimony of A. H. Beaumont, no. 4406.

53. Ibid., No. $4406: 388$, No. $4407: 389$.

54. FOGEL, R. W. \& S. L. ENGFRMAN. 1974. Time on the Cross: The Economics of American Negro Slavery. Vol. 1:210-217. Little Brown and Co. Boston, Mass.

55. BECKFORD, W. 1790. A Descriptive Account of the Island of Jamaica (2 vols.). Vol. II:318-319. London, England.

56. HALL, D. G. 1964. Absentee-proprietorship in the British West Indies to about 1850. Jamaican Historical Review IV:23-35.

57. BENNETT, J, H. 1958. Bondsmen and Bishops: Slavery and Apprenticeship on the Codrington Plantations of Barbados, $1710-1838$. :136-141. University of California Press. Berkeley, Calif.

58. Letters of $21 \mathrm{April}$ and $26 \mathrm{July}, 1773$. In Joseph Black's Correspondence, Vol. I: ff. 58-61. Manuscript Room, Edinburgh University Library.

59. Letter of 2 May, 1776. In MS. 3942, Robertson-Macdonald Letters. National Library of Scotland.

60. MORETON, J. B. 1793. West India Customs and Manners, etc. :18. London, England.

61. GRAINGER, J., M.D. An Essay on the More Common West-India Diseases; and the Remedies which that Country Itself Produces: To which are added, Some Hints on the Management, \&c. of Negroes. 2nd ed. With Practical Notes, and a Linnaean Index, by William Wright, M.D. F.R.S. (Edinburgh, 1802) :i-viii. See also The Dictionary of National Biography (cited hereafter as D.N.B.) 1890. L. Stephen and S. Lee, Eds. Vol. XXII:368-369. New York, N.Y.

62. 1828. Memoirs of the Late William Wright, M.D., Fellow of the Royal Societies of London and Edinburgh, ctc., With Extracts from His Correspondence and a Selection of His Papers on Medical and Botanical Subjects. :1-19. William Blackwood. Edinburgh, Scotland.

63. THOMSON, J.. M.D. 1820. A Treatise on the Diseases of Negroes, As They Occur in the Island of Jamaica: With Observations on the Country Remedies. :1-3. Alex. Aikman. Jamaica.

64. RAMSAY, J., op. cit. :viii, xiii.

65. RAMSAY, J. 1785. A Reply to the Personal Invectives and Objections Contained in Two Answers, Published by Certain Anonymous Persons, to An Essay on the Treatment and Conversion of African Slaves. :13-20. London, England; D.N.B., Vol. $\mathrm{XVI}: 689-690$.

66. STEPHEN, J. op. cit. :166-167, 173, 194-195, 283-285, 429-433; D.N.B., Vol. XVIII: $1048-1049$.

67. BOOTH, C. 1934. Zachary Macaulay: His Part in the Movement for the Abolition of the Slave Trade and of Slavery. An Appreciation. :2-13. Longmans, Green and Co. London, England.

68. D.N.B., Vol. XII: $418-420$. 